\title{
Effect of Marine Environment to the Concrete Beams Strengthened Using GFRP Sheet
}

\author{
Mufti Amir Sultan, Herman Parung, Wihardi Tjaronge, and Rudy Djamaluddin
}

\begin{abstract}
Structures built in aggressive environments such as in the sea/marine environment need to be carefully designed, due to possibility of chloride ion penetration into the concrete. One way to reduce the strength degradation in such environment is to use FRP, which is attached to the surface of $R / C$ using epoxy. The study presented is focused on determining the effect of the sea water to the capacity of GFRP as flexural reinforcement elements. Beams of $10 \times 10 \times 40 \mathrm{~cm}$ dimension were designed without reinforcing bars. The samples were tested using variation to the distance to the sea and duration of the contact to the sea.

The result showed that the use GFRP increased the flexural strength 84,21\%, compared to the normal beam, without GFRP. It can also be seen that the closer the distance to the sea, the higher the strength degradation of the beam. The sample rinsed in the water has strength $2.13 \mathrm{kN}$ after 9 months, while sample put at a distance $1 \mathrm{~km}$ from the seam has strength $2.53 \mathrm{kN}$. The result of this study also showed that for areas closer to the sea has a greater effect in terms decreasing flexural capacity of the beam
\end{abstract}

Index Terms-Flexural strength, GFRP, marine environment.

\section{INTRODUCTION}

Recently present the construction of the concrete structures around the beach line or even under water is increasing such as buildings, bridges, highway road, etc. Concrete structures that are not protected or close to the sea may be affected by corrosion, than if maintenance or preventive repairs is not done on the structure, it may cause the collapse [1].

Fiber Reinforced Plastics (FRP) has been accepted as an alternative material for the conventional steel reinforcement. Common FRP types are aramyd fiber reinforced plastic (AFRP), glass fiber reinforced plastics (GFRP), carbon fiber reinforced plastic (CFRP), respectively. FRP has been applied to many purposes for civil engineering structures not only for new structures but also for strengthening of the deteriorated structures. There has been an important increase in the use of FRP as strengthening structures with externally bonded, because of their inherent advantages in terms of light weight, high specific strength and stiffness ratios and their non corrosive properties [2], [3]. FRP has been developed in the various forms, such as grid, rod, sheet and plate. Glass fiber sheet as showed in Fig. 1 is most commonly used due to

Manuscript received March 15, 2014; revised May 27, 2014. This work was supported financially by the Directorate of Higher Education of Indonesia.

The authors are with the Civil Engineering Department of Hasanuddin University, Makassar, South Sulawesi, Indonesia (e-mail: muftiasltn@gmail.com, parungherman@yahoo.co.id, tjaronge@yahoo.co.jp rudy0011@hotmail.com). its relatively lower cost compared to the other FRP materials.

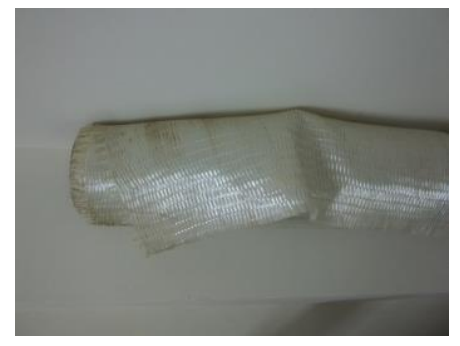

Fig. 1. Glass fiber sheet.

TABLE I: VARIATIONS IN BEAMS SPECIMEN

\begin{tabular}{|c|c|c|}
\hline $\begin{array}{l}\text { Name of } \\
\text { Specimen }\end{array}$ & Initial & $\begin{array}{l}\text { Distance from the } \\
\text { beach line } \\
(\mathrm{m})\end{array}$ \\
\hline $\mathrm{BN}$ & $\begin{array}{l}\text { Beam without GFRP external } \\
\text { reinforcement }\end{array}$ & $\begin{array}{l}---- \\
\end{array}$ \\
\hline $\mathrm{BF}$ & $\begin{array}{l}\text { Beam with GFRP external } \\
\text { reinforcement }\end{array}$ & ---- \\
\hline BF-1 & $\begin{array}{l}\text { Beam with GFRP external } \\
\text { reinforcement }\end{array}$ & Under water \\
\hline BF-2 & $\begin{array}{l}\text { Beam with GFRP external } \\
\text { reinforcement }\end{array}$ & 0 \\
\hline BF-3 & $\begin{array}{l}\text { Beam with GFRP external } \\
\text { reinforcement }\end{array}$ & 250 \\
\hline BF-4 & $\begin{array}{l}\text { Beam with GFRP external } \\
\text { reinforcement }\end{array}$ & 500 \\
\hline BF-5 & $\begin{array}{l}\text { Beam with GFRP external } \\
\text { reinforcement }\end{array}$ & 1000 \\
\hline
\end{tabular}

Studies using retrofitting of beams have been conducted by several researchers. Banthia (2009) reported that using GFRP composite materials in the area interested in the beams and plates. The increase of the moment capacity [4]. Rose et al., (2009) demonstrated that the strengthening of the corroded steel reinforced concrete increased ductility and ultimate strength [5]. Z. G. Guo et al., (2005) reported that using FRP composites were successfully used for strengthening of existing reinforced concrete structures because of their superior properties [6]. Alam F (2010) conducted research using GFRP as reinforcement flexural in reinforced concrete beams, The result indicated is an increasing in load up to $75.13 \%$ [7]. However further study needed to clarify the behaviour of beams with GFRP sheet reinforcement influenced by the marine environment.

\section{SPECIMEN AND TeSt SETUP}

\section{A. Specimen}

Fig. 2 shows the details of the test specimen. Concrete beams are prepared for this study with parameters of the bonding area GFRP sheet. The specimens were divided two types, which are strengthened reinforced external (BF) and 
beam without the external reinforcement $(\mathrm{BN})$. Table I shows variation specimen beams. The cross section of beam specimens was $10 \times 10 \mathrm{~mm}$ with the total length of $400 \mathrm{~mm}$. The concrete beams were cured before the application of the GRFP sheet. Compressive strength of concrete at 28 days was $25 \mathrm{MPa}$.

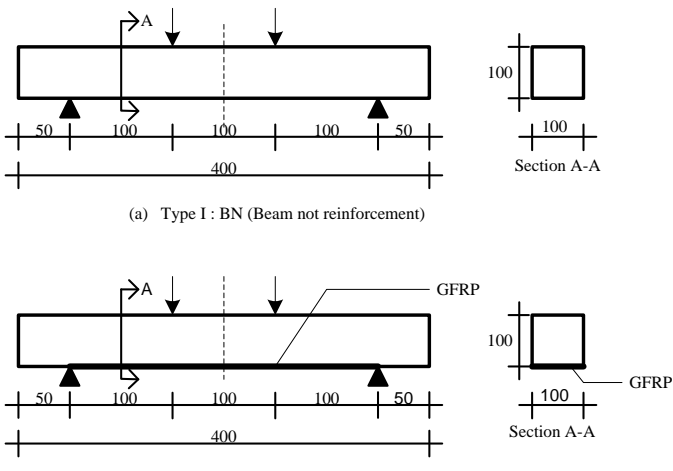

(b) Type II : BF (Beam with GFRP extrenal reinforcement)

Fig. 2. Detail of specimens.

Before the application of GFRP sheet, the bottom surfaces of the beam were smoothed by a disk sander. The epoxy resin was applied on the GFRP sheet placed on the table using a soft roller to impregnate all the fibers in the resin. The epoxy resin was applied on the treated surface using a soft roller before patching of the impregnated GFRP sheet to the treated surface. Fig. 3 shows installation of GFRP sheet on the beam.
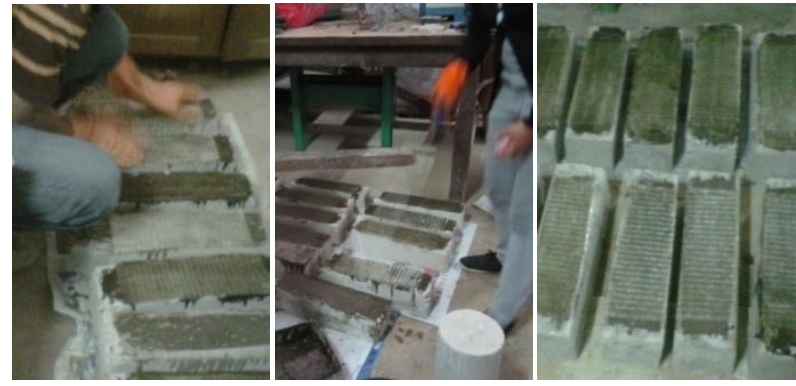

Fig. 3. Installation of GFRP sheet on the beam.

The patched GFRP sheet was positioned with the application of slight pressure using a soft roller. Table II shows the material properties of the manufacturer data GFRP sheet, and Table III shows the manufacturer data of epoxy resin, respectively.

\section{TABLE II: MATERIAL PROPERTIES OF GFRP}

\begin{tabular}{lc}
\multicolumn{1}{c}{ TABLE } & Glass Fiber \\
\hline \hline Tensile strength $(\mathrm{MPa})$ & 22.20 \\
Modulus Young $(\mathrm{GPa})$ & 22.14 \\
Laminate Thickness $(\mathrm{mm})$ & 3.3 \\
\hline \hline
\end{tabular}

\begin{tabular}{lc}
\multicolumn{2}{c}{ TABLE III: MATERIAL PROPERTIES OF EPOXY RESIN } \\
\hline \multicolumn{1}{c}{ Items } & Properties \\
\hline Tensile strength $(\mathrm{MPa})$ & 72.4 \\
Modulus Young $(\mathrm{GPa})$ & 3.18 \\
Bending Strength $^{*}(\mathrm{MPa})$ & 2.12 \\
\hline \hline
\end{tabular}

${ }^{*}$ Based on the tensile test

\section{B. Test Setup}

At this study, the beam specimens are placed at five locations as follows: under water, the beach line, $250 \mathrm{~m}, 500$ $\mathrm{m}$ and $1000 \mathrm{~m}$ from beach line. Beam specimens were placed for one, three, six and nine months. Fig. 4 shows location the placement of the sample.

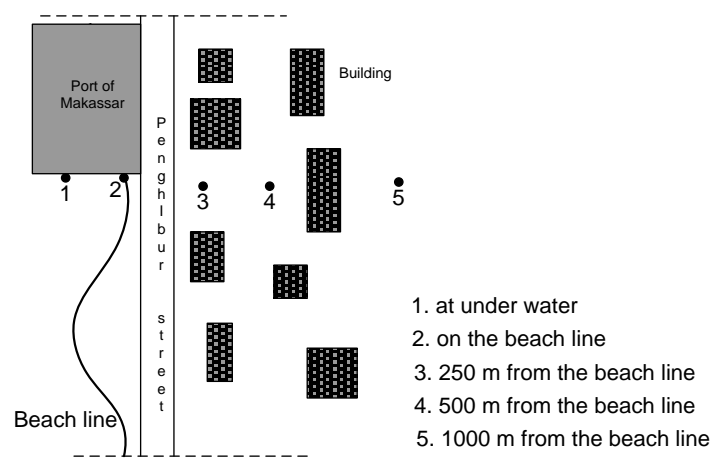

Fig. 4. Location the placement of the samples.

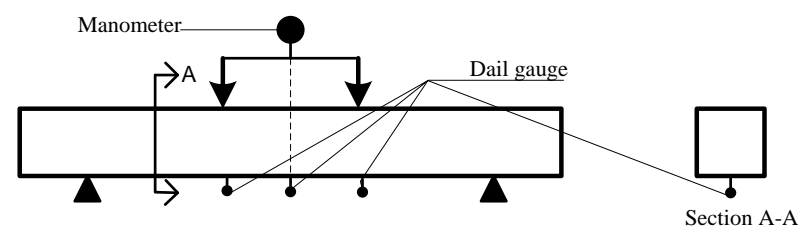

Fig. 5. Test setup.

The beams specimens were tested under simple supported beams subjected to two point loads using a universal testing machine, as shown in Fig. 5. Each specimen was instrumented by dial gauges and manometer, respectively. The deflection and loading were measured using dial gauge and manometer.

\section{RESUlT AND DISCUSSION}

\section{A. Flexural Capacities}

Fig. 6 shows the moment capacity of the beam specimen $\mathrm{BN}$ and BF. It can be observed that the beam specimens using external GFRP sheet reinforcement increase flexure capacity of up to $84,21 \%$.

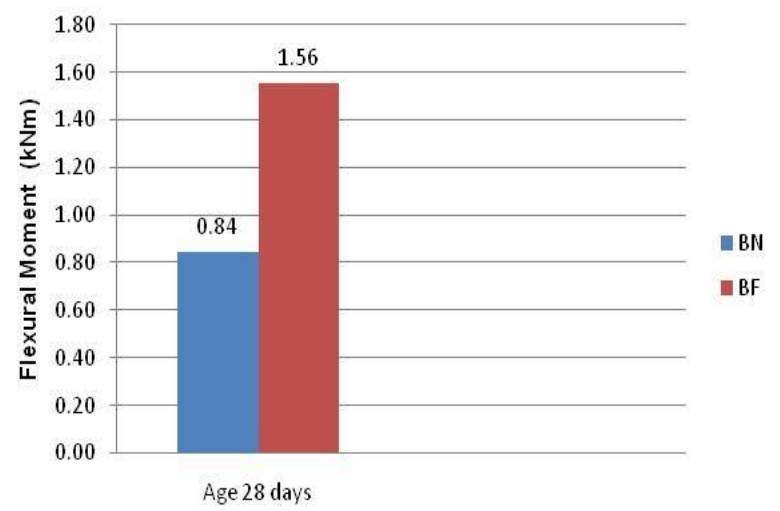

Fig. 6. Flexure capacity of the specimens beam BF and BN.

Fig. 7 - Fig. 10, shows the load-deflection relationship of the specimens BF1, BF2, BF3, BF4 and BF5. It can be observed that type has similar flexural behavior up to failure. Initially the GFRP sheet resisted of tension forces. On the flexural beams, the rupture bonding stress of the GFRP may be influenced also the flexural cracking. The farther the distance from beach line of the beam capacity increased by 
$18.75 \%$

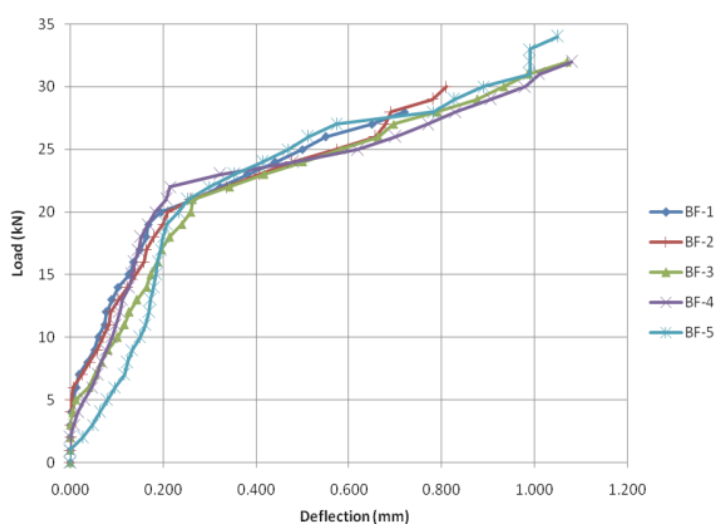

Fig. 7. Load-deflection curve (one month).

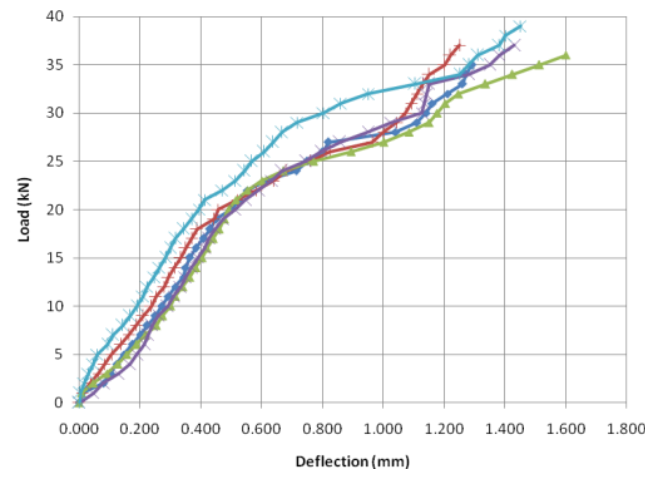

Fig. 8. Load-deflection curve (three months)

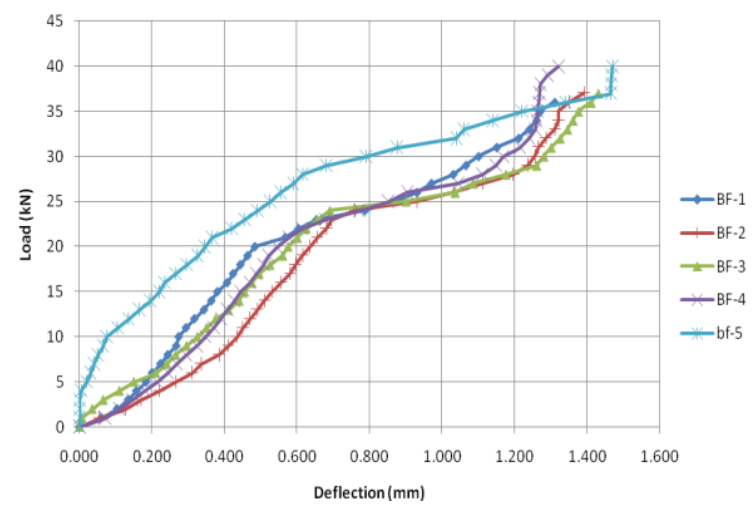

Fig. 9. Load-deflection curve (six months).

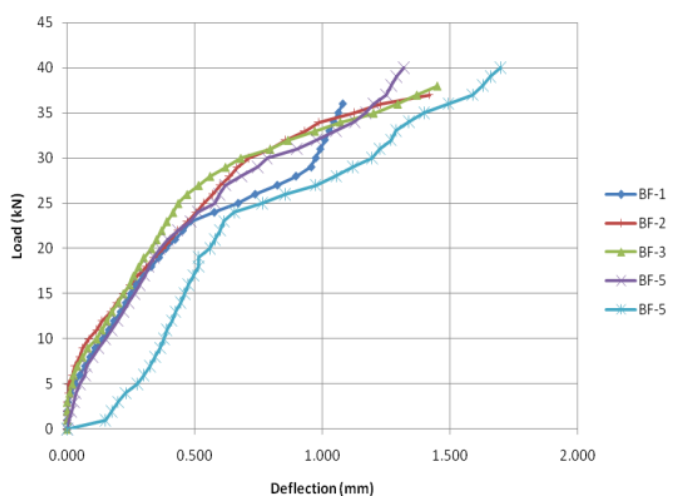

Fig. 10. Load-deflection curve (nine months).

Table III presents the decrease in the maximum deflection and maximum moment capacity of specimen after 6 months on average $1.87 \%$ and $8.75 \%$. This indicates that after 6 months of contact with the marine environment beam strength degradation.

TABLE IV: SUMMARY OF MOMEN MAXIMUM AND DEFLECTION MAXIMUM

\begin{tabular}{|c|c|c|c|}
\hline Specimen & $\begin{array}{l}\text { Contact duration } \\
\text { of the marine } \\
\text { environment } \\
\text { (month) }\end{array}$ & $\begin{array}{l}\text { Maximum } \\
\text { moment } \\
(\mathrm{kN} . \mathrm{m})\end{array}$ & $\begin{array}{c}\text { Deflection at } \\
\text { Mmax } \\
(\mathrm{mm})\end{array}$ \\
\hline \multirow{4}{*}{ BF1 } & 1 & 1.58 & 0.720 \\
\hline & 3 & 2.00 & 1.080 \\
\hline & 6 & 2.16 & 1.310 \\
\hline & 9 & 2.13 & 1.290 \\
\hline \multirow{4}{*}{ BF2 } & 1 & 1.82 & 0.810 \\
\hline & 3 & 2.16 & 0.141 \\
\hline & 6 & 2.44 & 1.420 \\
\hline & 9 & 2.38 & 1.390 \\
\hline \multirow{4}{*}{ BF3 } & 1 & 1.89 & 1.050 \\
\hline & 3 & 2.27 & 1.25 \\
\hline & 6 & 2.40 & 1.450 \\
\hline & 9 & 2.37 & 1.320 \\
\hline \multirow{4}{*}{ BF4 } & 1 & 2. 11 & 1.080 \\
\hline & 3 & 2.27 & 1.320 \\
\hline & 6 & 2.47 & 1.700 \\
\hline & 9 & 2.40 & 1.320 \\
\hline \multirow{4}{*}{ BF5 } & 1 & 2.13 & 1.070 \\
\hline & 3 & 2.49 & 1.600 \\
\hline & 6 & 2.57 & 1.450 \\
\hline & 9 & 2.53 & 1.430 \\
\hline
\end{tabular}

\section{B. Effect of Distance}

Fig. 11 and Fig. 12, show that after 6 months reduces the flexural capacity of an average of $1.87 \%$. Sample at a distance of $1000 \mathrm{~m}$ from the line beach to the load capacity reduction is of $1.32 \%$ compared to that located on the line beach of $2.80 \%$. This indicates that the reduction in beam flexural capacity is greater for areas and closer to the sea.

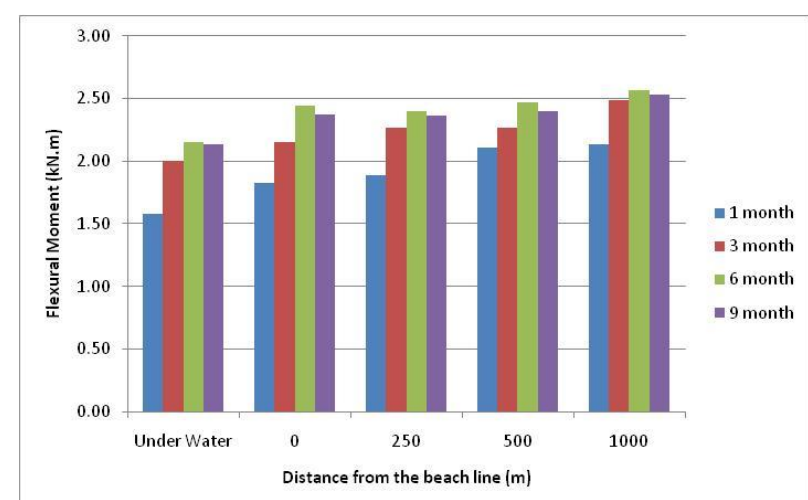

Fig. 11. relationship the flexural moment and the distance from the beach line.

\section{Failure Mode}

Based on the results of flexural was testing of specimen beams as shown in Fig. 9, pattern of cracks occurred at the 1/3 of the span, so it can be said to be cracked due to flexural moment. The results of these observations are also the basis for the calculation of flexural strength by using the appropriate formula references used.

In this test the beam flexural fractured, It can be seen from the crack pattern direction vertical to the longitudinal axis of the beam. Crack generally occurs at the mid span right under 
load. If the load continues to increase and the cracks are already beginning to happen more and more length to the width and cross section neutral axis, thereby reducing the stiffness of the beam.

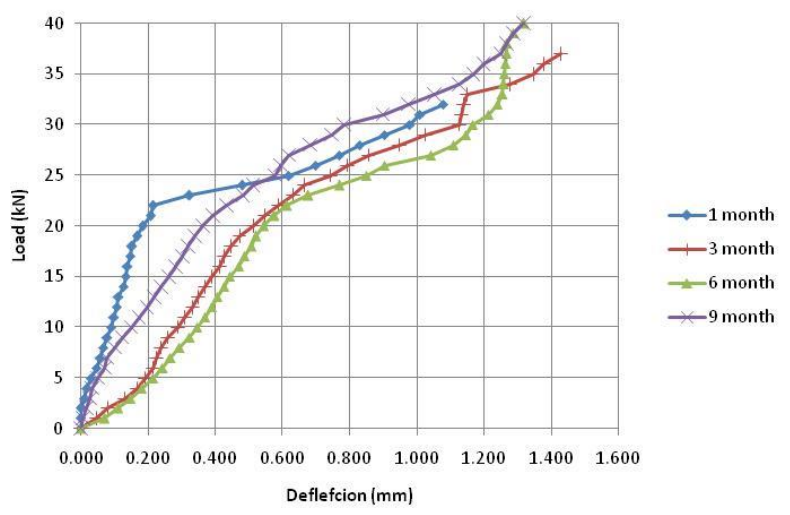

Fig. 12. Load-deflection curve (BF 5).
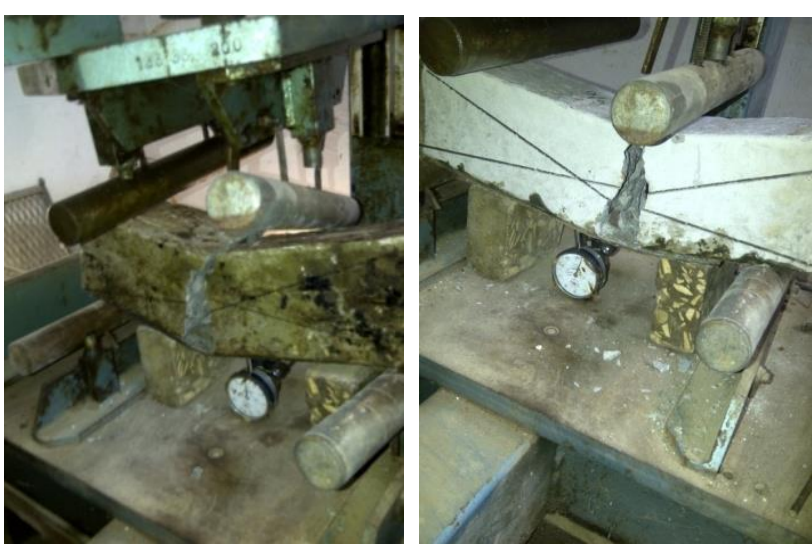

Fig. 12. specimen beam pattern collapse.

\section{CONCLUSION}

This study revealed that concrete beams with GFRP external reinforcement flexural strength increased by $84.21 \%$, The sample rinsed in the water has strength $2.13 \mathrm{kN}$ after 9 months, while sample put at a distance $1 \mathrm{~km}$ from the sea has strength $2.53 \mathrm{kN}$, the results of this study also showed that for areas closer to the sea has a greater effect in terms of decreasing flexure capacity of the beam.

\section{ACKNOWLEDGMENT}

Thanks and appreciation for the magnitude of the PT. Graha Anugerah Citra Lestari who have contributed GFRP type SEH51 on our research, to PT. Pelindo IV, Makassar Port Authority, which has helped the students in this study as well as the staff Structures and Materials Laboratory of the Department of Civil Engineering, Faculty of Engineering, Hasanuddin University.

\section{REFERENCES}

[1] M. G. Strewat, "Effect of spatial variability of pitting corrosion and its influence on structural fragility and reliability of reinforced concrete beam in flexural," Structural Safety, vol. 26, no. 4, pp. 453-470, 2004.

[2] R. Masmoudi, G. Nkrunziza, B. Benmokrane, and P. Cousin, "Durability of glass FRP composites bars for concrete structure reinforcement under tensile sustained load in wet alkaline environments," presented at Annual Conference of the Canadian Society for Civil Engineering, Moncton, Nouveau-Brunswick, Canada, June 4-7, 2003.

[3] J. G. Teng and J. F. Chen, "Debonding failures of RC beams strengthened with externally bonded FRP reinforcement: Behaviour and modeling," presented at Asia-Pasific Conference on FRP in Structures (APFIS 2007).

[4] N. Banthia, A. Abdolrahimzadeh, and M. Boulfiza, "Filed assessment of FRP sheet-concrete bond durability," presented at $1^{\text {st }}$ International Conference on Sustainable Built Environment Infrastructures in Developing Countries (SEIBDCO), Algeria, October 12-14, 2009.

[5] A. Leema. Rose, K. Suguna, and P. N. Ragunath, "Strengthening of corrosion-damaged reinforced concerete beams with glass fiber reinforced polymer laminates," Journal of Computer Science, vol. 5, no. 4, pp. 435-439, 2009.

[6] Z. G. Guo, S. Y. Cao, W. M. Sun, and X. Y. Lin, "Experimental study on bond stress-slip behaviour between FRP sheets and concrete," in Proc. the International Symposium on Bond Behaviour of FRP in Structures (BBFS 2005), pp. 77-83, 2005.

[7] F. Alam, "Flexural retrofitting of reinforced concrete beams with glass fiber reinforced polymer (GFRP)," presented at HAKI Conference, Jakarta, 2010.

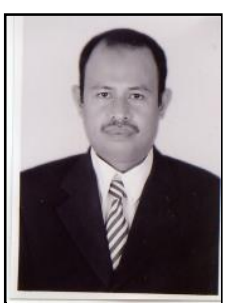

Mufti Amir Sultan is a lecturer at the Department of Civil Engineering Khairun University, Ternate, North Maluku, Indonesia. He was born on Februari 27, 1972. He received his BS from Hasanuddin University, MS from Hasanuddin University, now a doctoral student at the Hasanuddin university.

He was awarded by some research grant such as: Research grant from the ministry of the Indonesian Higher Education on 2009 and 2013, Research grant from Center for research and development area of North Maluku on 2011 and 2013. 